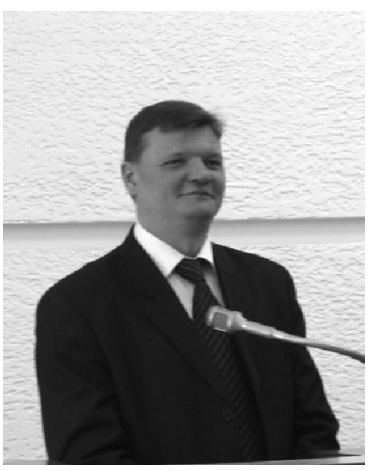

Галушко О.A.

\title{
СИНДРОМ ОБСТРУКТИВНОГО
} AПНОЕ СНУ У ХВОРИХ НА ГОСТРИЙ ІНСУЛЬТ: ДІАГНОСТИКА I ТАКТИКА РЕСПІРАТОРНОÏ ПІДТРИМКИ

\author{
Національна медична академія післядипломної освіти \\ імені П.Л.Шупика, м. Київ
}

\begin{abstract}
В результаті проведеного дослідження встановлено, що вірогідність виникнення синдрому обструктивного апное сну (СОАС) у хворих на гострий інсульт (ГІ) є високою (63,3\%). Факторами ризику є чоловіча стать, цукровий діабет (ЦД), ожиріння, високий бал за NIHSS (Г15). 3 метою діагностики СОАС і визначення подальшої тактики респіраторної підтримки у цих хворих при поступленні потрібно проводити скринінг-діагностику. Особливостями розвитку СОАС у пацієнтів 3 ГІ та супутнім ЦД є швидке покращення показників у 1-3 дні лікування та потреба в тривалій терапії на подальших етапах. Тактика респіраторної підтримки у цих хворих повинна бути наступною. При виявленні хворих з «м'яким» COAC (IAГ 5-15) проводиться «позиційна» терапія 3 метою максимального зменшення часу перебування хворого в положенні на спині. У хворих 3 IAГГ 15 слід застосовувати методику ранньої неінвазивної вентиляційної корекції з використанням постійного позитивного тиску в дихальних шляхах (СРАР). У разі виявлення у хворого СОАС тяжкого ступеню (IАГ > 20) та відсутності ефекту від CРАР-терапії протягом 2-3 діб, хворим показано переведення на ШВЛ 3 ранньою трахеостомією (метод вибору - черезшкірна дилятаційна трахеостомія).
\end{abstract}

Ключові слова: інсульт, цукровий діабет, синдром обструктивного апное сну, неінвазивна респіраторна підтримка, СРАР-терапія, дилятаційна трахеостомія.

\section{ВСТУП}

Синдром обструктивне апное сну $(\mathrm{COAC})$ - це патологічний стан, що характеризується періодичним пригніченням (гіпопное) або припиненням (апное) повітряного потоку через звуження верхніх дихальних шляхів під час сну, часто супроводжується гіпоксемією і розладами сну [11]. Припинення легеневої вентиляції при дихальних зусиллях веде до зниження рівня кисню в крові, затримки $\mathrm{CO}_{2}$, активації симпатичної нервової системи і вазоконстрикції [1]. Патологічним вважається виникнення епізодів апное під час сну 3 частотою більше 5 за год і тривалістю більше 10 с кожний, що супроводжується дихальною недостатністю і порушенням інших функцій організму, а також вираженою сонливістю в денний час $[2,4]$.
Поширеність СОАС у загальній популяції становить за різними оцінками від $2 \%$ до $25 \%$. Наявність СОАС у хворого асоціюється 3 підвищенням частоти виникнення гіпертонії, ішемічної хвороби серця, інсульту, передчасної смерті і автомобільних аварій [13].

COAC є одним 3 тяжких ускладнень перебігу гострого інсульту (ГІ). Серед патогенетичних механізмів цих розладів слід назвати зміни в контролі за диханням, порушення респіраторної механіки і дихального паттерну. За спостереженнями японських авторів, при гострих порушеннях мозкового кровообігу частота нічних порушень дихання складала: 75\% пацієнтів 3 TIA, 86\% 3 ішемічним інсультом, $80 \%$ з атеросклерозом великих артерій, $100 \%$ з оклюзіями невеликих

○ Галушко O.A., 2017 
судин, 90\% 3 кардіоемболіями і $81 \% 3$ іншими причинами інсульту [9]. При цьому тяжкий COAC був наявним в $29 \%$ пацієнтів.

Значно ускладнюється ситуація у тих хворих, у яких інсульт розвинувся на фоні тяжкої системної патології, наприклад, на тлі цукрового діабету (ЦД). У хворих на ГІ із супутнім ЦД системне запалення, судинні розлади, коагулопатія, гіперглікемія і ацидоз можуть сприяти поглибленню ішемії тканин $[5,6]$ і приводити до розвитку ускладнень перебігу ГІ, в тому числі до розладів зовнішнього дихання. За даними різних авторів, частка COAC у пацієнтів з ЦД складає від 37,4 до $67,3 \%$ серед хворих на ЦД $[7,8,14]$.

Таким чином, при ЦД у разі розвитку гострого інсульту ризик виникнення СОАС $\epsilon$ високим. Проте в доступній літературі нам не вдалося розшукати публікацій про особливості розвитку COAC у хворих із поєднаною патологією - гострим інсультом та цукровим діабетом, що й зумовило необхідність цього дослідження.

\section{META}

Виявити частоту виникнення і особливості перебігу синдрому обструктивного апное сну у хворих на гострий інсульт із супутнім цукровим діабетом та визначити тактику респіраторної підтримки у цих пацієнтів.

\section{МАТЕРІАЛИ I МЕТОДИ}

Дослідження проведено у відділенні інтенсивної терапії К3 КОР «Київська обласна клінічна лікарня». Всього було обстежено 300 хворих (180 чоловіків і 120 жінок) віком від 46 до 82 років, у яких при госпіталізації був встановлений діагноз гострого ішемічного інсульту з коморбідним ЦД. Тяжкість інсульту оцінювали за шкалою NIHSS. За наявності свідомості або чітких відомостей від родичів проводили оцінку анамнестичних ознак COAC за шкалою Epworth Sleepiness Scale [12].

Скринінг на тяжкість СОАС проводили 3 використанням комплексу SOMNOcheck micro (Weinmann, Німеччина). Для оцінки тяжкості COAC визначали індекс апноегіпопное (ІАГ): загальна кількість епізодів апное і гіпопное, виявлених при спосте- реженні за весь період сну, ділиться на загальну кількість годин сну. ІАГ від 5 до 15 трактується як СОАС легкого ступеню (м'який), від 15 до 30 - СОАС середньої тяжкості (помірний), при наявності у хворого ІАГ $\leq 30$ діагностується СОАС тяжкого ступеню [4]. Обраховували також тривалість епізодів апное, форму апное (центральне чи обструктивне) та індекс десатурації (кількість епізодів зниження оксигемоглобіну більше ніж на 4\% протягом 1 год сну). За сумою отриманих показників визначали ступінь тяжкості COAC та потребу у респіраторній підтримці.

При виявленні хворих 3 «м'яким» СОАС (ІАГ 5-15) проводилася «позиційна» терапія, що включала регулярну зміну положення тіла 3 метою максимального зменшення часу перебування хворого в положенні на спині.

У хворих з ІАГ Г 15 застосовували методику ранньої неінвазивної вентиляційної корекції з використанням постійного позитивного тиску в дихальних шляхах (CРAP) у поєднанні з 40\% фракцією кисню у повітрі, що вдихається. Для СРАР-терапії використовували апарат VENTImotion 2 (Weinmann, Німеччина), який забезпечував безклапанний контур пацієнта, максимальний тиск на вдиху - 30 гПа, дихальний об'єм 160-3000 мл, частоту дихання 6-45 за хв, систему технічних та фізіологічних тривог. Критерієм досягнення ефективного лікувального тиску вважали зникнення апное, гіпопное, хропіння, дискоординації торако-абдомінальних рухів і мікропробуджень.

У разі виявлення у хворого СОАС тяжкого ступеню (IAГ > 20) проводили пробний курс позиційної терапії в поєднанні 3 описаною вище методикою СРАР-терапії. У випадку, якщо протягом 2-3 діб спостерігалося покращення показників СОАС продовжували розпочату терапію у поєднанні з комплексом IT гострого інсульту. У випадках, коли значного ефекту від СРАРтерапії не спостерігалося, хворим рекомендували переведення на ШВЛ $з$ ранньою трахеостомією.

Рання трахеостомія у таких пацієнтів виконувалася транскутанним способом як пункційно-дилятаційним трахеостомія (ПДТ) за удосконаленим алгоритмом. Цей алгоритм був введений у практику ВIT 


\section{ORIGINAL RESEARCH}

КОКЛ у 2015 році. За період 2015-2017 роки, у ВІТ КОКЛ проведено 246 ПДТ різним групам пацієнтів, що знаходились на ШВЛ. Серед основних нозологій ця маніпуляція була проведена 89 хворим на ГПМК. 3 апробованих методик ПДТ найзручнішим виявився метод Сіглі фірми Rusch, набір «PercuTwist» 3 гвинтоподібним розширювачем.

Операція трахеостомії проводилася під загальною анестезією із застосуванням міорелаксантів для попередження кашлю під час пункції трахеї. У разі наявності фібробронхоскопу весь хід операції контролювався візуально через ендотрахеальну

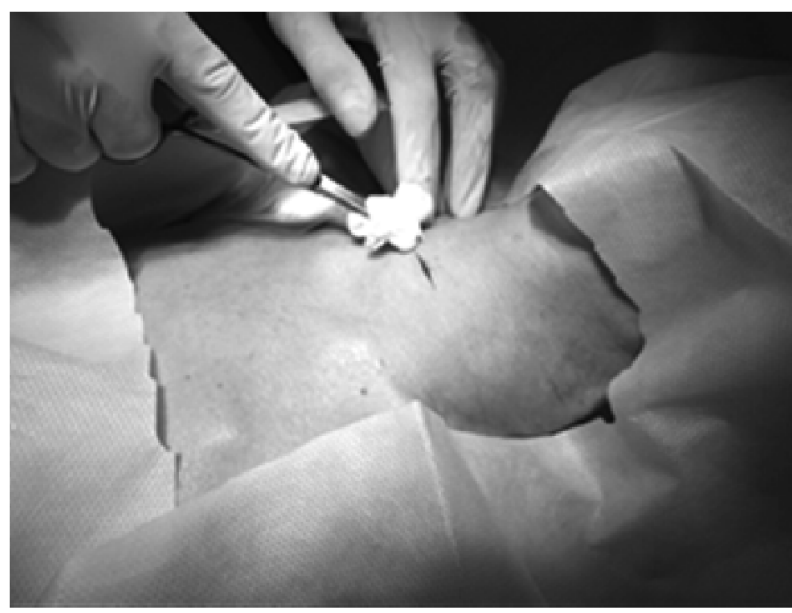

Puc.1.A

Канюлю залишали у просвіті трахеї, голку видаляли. Далі за методом Сельдингера проводили гнучкий металевий провідник, по якому гвинтоподібний буж «вкручували» у трахею (рис.2.А, 2.Б).

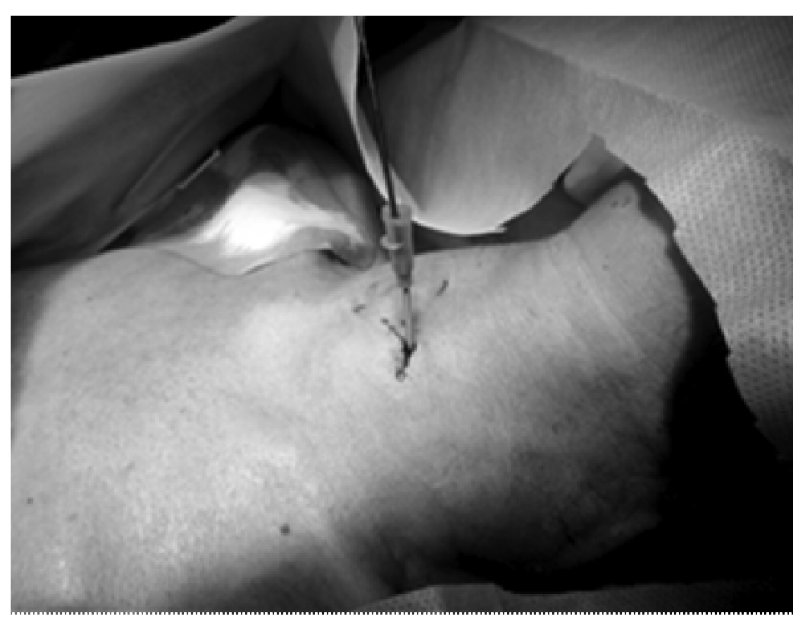

Puc. 2.A

\section{PAIN, ANAESTTHESIA \& INTENSIVE GARE NA 2017}

трубку (ЕTT) із застосуванням спеціального конектору, що дозволяло проводити адекватну ШВЛ під час операції. За відсутності бронхоскопу, після пункції ЕТТ зміщували декілька разів догори й униз на 2-3 мм. Якщо під час пункції голка проходила через ЕTT або впиралася у трубку, проводилася корекція положення ЕTT і повторна пробна пункція. Надійним підтвердженням знаходження голки у просвіті трахеї було повітря, отримане у шприці з фізіологічним розчином.

Безпосередньо на шкірі робили поперечний розріз скальпелем, після цього проводили пункцію голкою 3 канюлею $14 \mathrm{G}$ (рис.1.А, 1.Б).

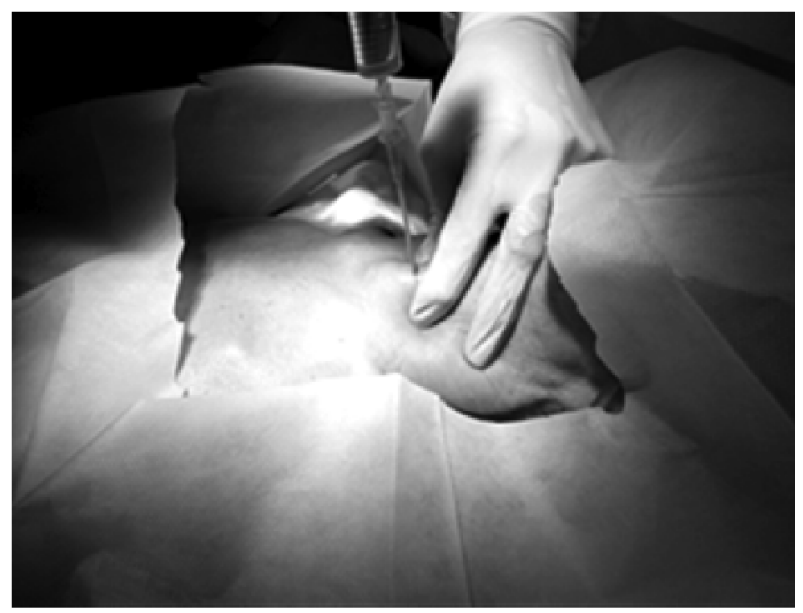

Puc.1.5

Коли стома була сформована, гвинтоподібний буж видаляли (рис.3.А та рис.3.Б).

На його місце по провіднику встановлювали необхідного розміру трахеостомічну трубку і хворого під'єднували до респіратора (рис.4.А та рис.4.Б).

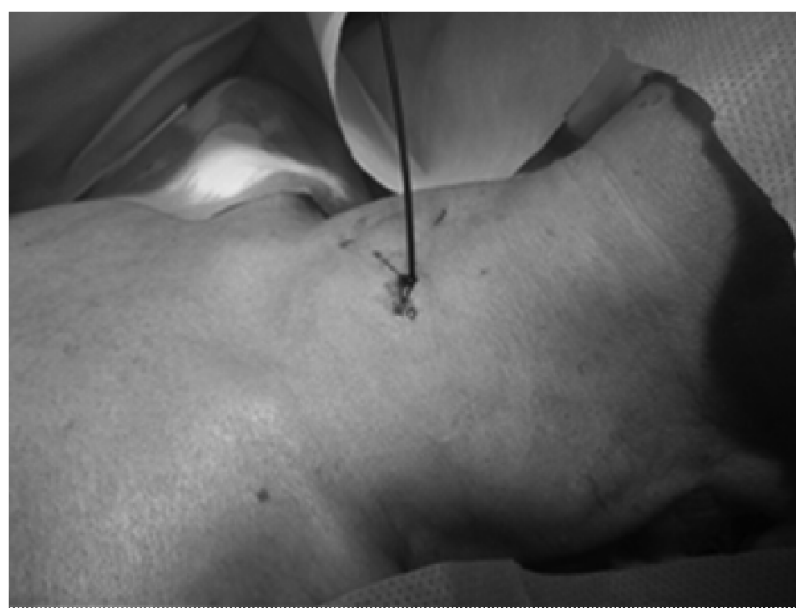

Puc.2.5 


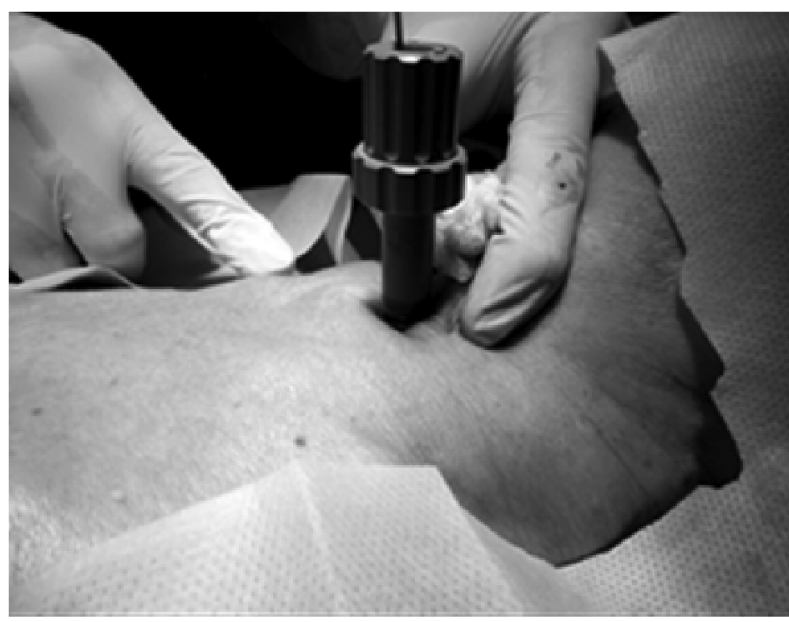

Puc.3.A

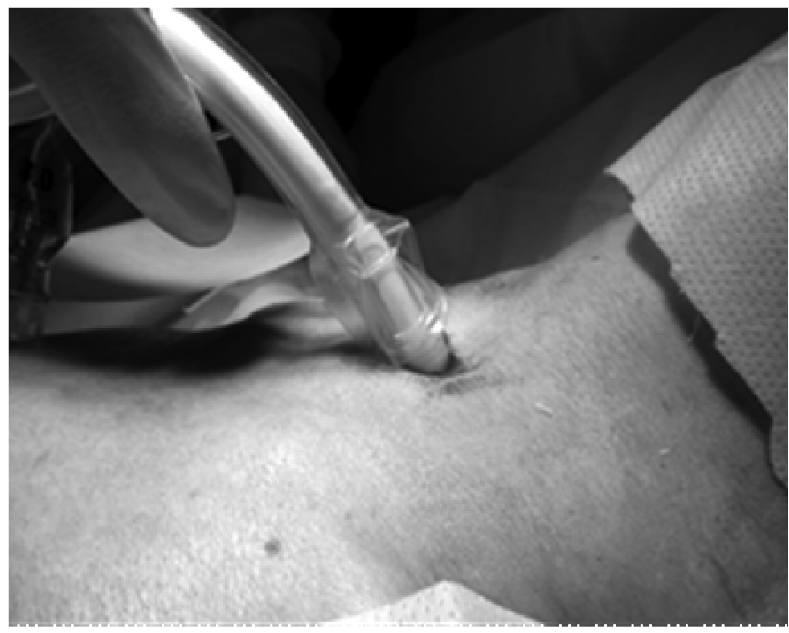

Puc.4.A

\section{РЕЗУЛЬТАТИ ТА ÏХ \\ ОБГОВОРЕННЯ}

Серед 300 обстежених хворих на ГІ, ознаки COАС (IАГ Г 5) були виявлені у 190 пацієнтів $(63,3 \%) .3$ метою вирішення поставленого завдання - оцінити характеристику перебігу респіраторних порушень було створено дві групи. Хворі з ознаками СОАС увійшли в основну групу дослідження (група СОАС). У 110 хворих ознак СОАС виявлено не було (ІАГ $<5)$, і вони увійшли до групи контролю. Загальна характеристика груп дослідження представлена у табл. 1.

Аналізуючи дані, представлені в таблиці 1, слід зазначити, що в основній групі хворих, у яких було виявлено СОАС, значно переважали чоловіки (78,9 проти $27,3 \%$ в контрольній групі), був дещо вищим серед-

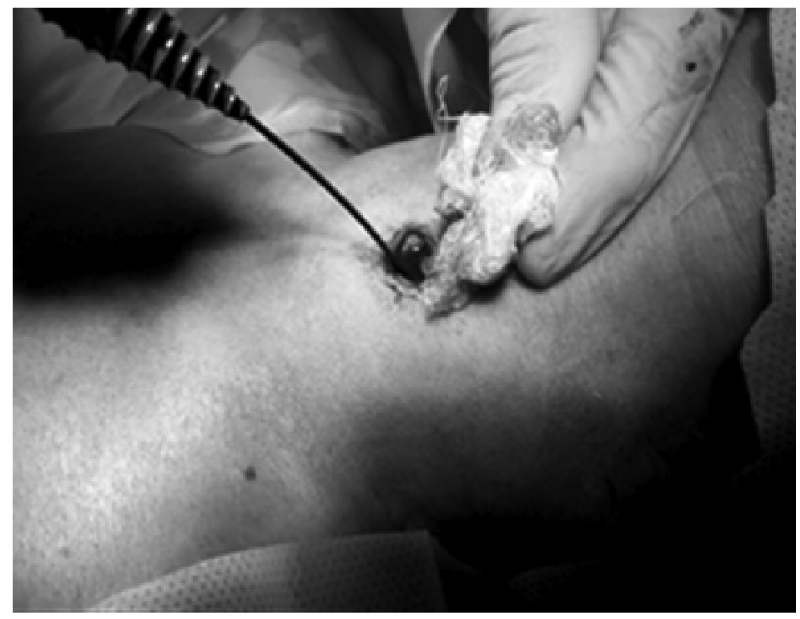

Puc.3.5

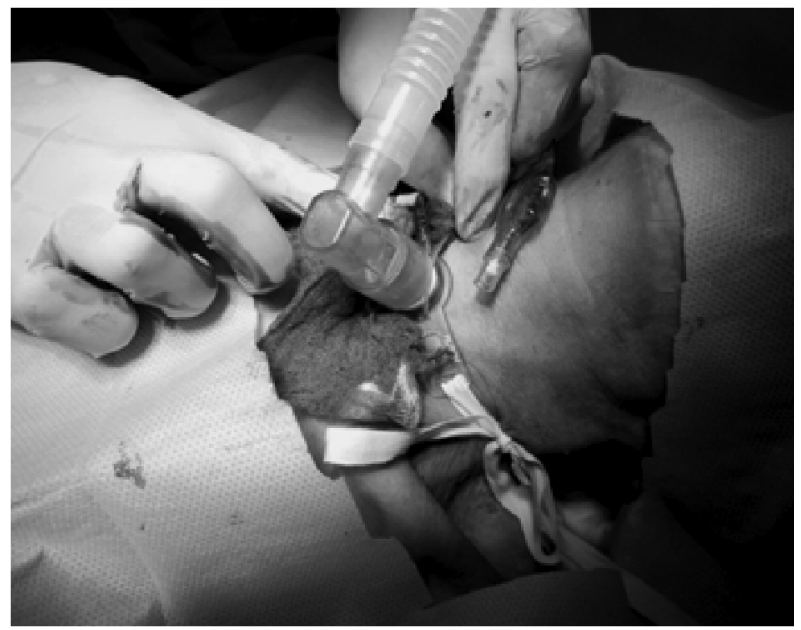

Puc.4.5

ній бал за шкалою NIHSS та частіше виявлялося ожиріння (IMT Г $30 \kappa г / \mathrm{m}^{2}$ ). В обох групах майже відсутніми були хворі з ЦД 1 типу, що пояснюється патогенетичними особливостями виникнення та розвитку діабетичних ангіопатій [3]. Не спостерігалося різниці в тривалості ЦД та наявності гіпертонічної хвороби.

Після виявлення СОАС проводилась описана вище корекція респіраторних розладів, а контрольні вимірювання проводилися на 3-й, 7-й та 10-й дні лікування. Результати дослідження підсумовані у таблиці 2.

Аналіз проведеного обстеження та лікування хворих дав підстави до цікавих висновків. По-перше, звертає на себе увагу суттєве покращення показників між 1 та 3 днями. Зокрема, значно знизилися показники індексу АНI, зменшилася тривалість епізоду апное, зменшилися відсоток часу 
Таблиця 1. Характеристика груп хворих на ГI, у яких визначали ознаки СОАС

\begin{tabular}{l|c|c}
\hline \multicolumn{1}{c|}{$\quad$ Характеристики } & COAC & Без СОАС \\
\hline Кількість хворих & 190 & 110 \\
\hline Вік, роки & $62,6 \pm 12,7$ & $63,1 \pm 14,1$ \\
\hline Стать, чоловіки (\%) & $150(78,9)^{*}$ & $30(27,3)^{*}$ \\
\hline Оцінка за NIHSS, бали & $14,3 \pm 3,7^{*}$ & $10,9 \pm 2,8^{*}$ \\
\hline Тип ЦД, $\mathrm{n}$ та \% 2 типу & $180(94,7)$ & $110(100)$ \\
\hline Тривалість ЦД, роки & $5,6 \pm 3,8$ & $6,0 \pm 2,9$ \\
\hline Гіпертонічна хвороба, $\mathrm{n}(\%)$ & $120(63,1)$ & $70(63,6)$ \\
\hline Ожиріння, $\mathrm{n}$ (\%) & $130(68,4)^{*}$ & $50(45,4)^{*}$ \\
\hline *-різниця між групами статистично достовірна $(p<0,05)$. & &
\end{tabular}

Табличя 2. Визначення параметрів COAC на етапах лікування (Me \pm SE)

\begin{tabular}{|c|c|c|c|c|}
\hline \multirow{2}{*}{ Параметри } & \multicolumn{4}{|c|}{ Дні лікування } \\
\hline & 1 & 3 & 7 & 10 \\
\hline АНl, індекс апное-гіпопное, год ${ }^{-1}$ & $19,7 \pm 4,6$ & $9,8 \pm 3,4^{*}$ & $9,3 \pm 2,8$ & $9,0 \pm 3,4$ \\
\hline Середня тривалість апное, с & $20,9 \pm 12,5$ & $15,3 \pm 4,9^{*}$ & $14,9 \pm 6,1$ & $13,8 \pm 5,6$ \\
\hline Максимальна трив алість апное, с & $29,5 \pm 8,7$ & $27,6 \pm 4,7$ & $26,9 \pm 4,2$ & $26,0 \pm 7,3$ \\
\hline цАНІ, частота цент ральних подій, год ${ }^{-1}$ & $5,2 \pm 3,6$ & $4,3 \pm 3,9$ & $3,9 \pm 3,6$ & $3,8 \pm 2,7$ \\
\hline оАНІ, частота обструкт ив них подій, год ${ }^{-1}$ & $8,1 \pm 5,6$ & $2,3 \pm 2,1^{*}$ & $2,4 \pm 2,3$ & $2,3 \pm 1,9$ \\
\hline Сумарна тривалість апное на 1 год сну, хв. & $12,1 \pm 5,8$ & $7,9 \pm 4,7^{*}$ & $7,1 \pm 5,2$ & $7,0 \pm 4,2$ \\
\hline Індекс десатурації, год ${ }^{-1}$ & $10,7 \pm 5,8$ & $9,8 \pm 4,9$ & $8,7 \pm 5,6$ & $7,9 \pm 4,2$ \\
\hline $\mathrm{SpO}_{2}$ середня, \% & $92,1 \pm 2,9$ & $93,6 \pm 3,4$ & $94,0 \pm 2,8$ & $94,2 \pm 2,9$ \\
\hline $\mathrm{SpO}_{2}$ мінімальна, \% & $81,4 \pm 4,9$ & $84,7 \pm 2,3$ & $85,6 \pm 3,9$ & $84,9 \pm 4,8$ \\
\hline $\mathrm{SpO}_{2}<85 \%, \%$ від загального часу сну & $5,6 \pm 3,9$ & $2,8 \pm 1,1^{*}$ & $2,7 \pm 0,9$ & $1,9 \pm 0,8$ \\
\hline
\end{tabular}

сну, під час якого у хворого рівень $\mathrm{SpO}_{2}$ був нижче $85 \%$, і сумарна тривалість апное на 1 год сну. Таке покращення параметрів вентиляції було досягнуто за рахунок різкого (майже в 4 рази) зменшення частоти обструктивних подій, тоді як частота центрального апное практично не змінилася. Це можна пояснити тим, що центральне апное більше залежить від розміру та розташування зони інфаркту мозку. А зниження частоти обструктивного апное в такому випадку слід розглядати як ефект лікування.

Друге цікаве спостереження. Протягом лікування між 3 та 7 днями показники сомнографії практично не змінилися - по жодному 3 досліджених параметрів не було виявлено статистично достовірної різниці, хоча й спостерігалася тенденція до деякого покращення результатів. Такі ж тенденції виявлені і на проміжку 7-10 днів лікування. Ми можемо пояснити цей факт тим, що за 3-7 днів не можуть бути усунуті основні фактори ризику розвитку СОАС, такі як ожиріння, гіпертонія, метаболічний синдром, куріння, зловживання алкоголем та інші, а отже лікування СОАС у хворих на ГI та ЦД потрібно проводити тривало. Це $є$ важливим завданням наступного - реабілітаційного етапу лікування хворих на ГІ.

В цілому зазначена методика обстеження та респіраторної терапії добре переносилися пацієнтами. 3 несприятливих подій під час неінвазивної вентиляційної корекції були відмічені блювання, аспіраційна пневмонія (в 1-му випадку), гіпотензія, що не вимагала застосування вазопресорів, а також поверхові ушкодження шкіри обличчя. Відзначені побічні ефекти були поодинокими і не впливали на загальні 
наслідки лікування. Зокрема, виявилося, що неврологічне поліпшення протягом госпіталізації мало тенденцію до покращення в групі неінвазивної вентиляції (оцінка за NIHSS в середньому знизилася на 3 бали) в порівнянні з групою контролю (середня оцінка за NIHSS знизилася на 1-2 бали). Таким чином, є підстави вважати, що у пацієнтів з ГІ і COAC неінвазивна респіраторна підтримка може бути розпочата рано при гарній переносимості і невеликому ризику розвитку побічних ефектів.

При порівнянні результатів використання різних методик трахеотомії у ВIT Київської обласної клінічної лікарні було встановлено, що черезшкірна ПДТ має низку переваг перед традиційною методикою трахеостомії. Зокрема, особливості техніки виконання дилятаційної трахеостомії дозволяють виконувати її в значно більш короткі терміни, ніж традиційну. Так, час виконання маніпуляції в основній групі наших пацієнтів склав $10,8 \pm 3,6$ хв, тоді як в групі контролю $49,7 \pm 12,3$ хв $(\mathrm{p}<0,01)$.

\section{ВИСНОВКИ}

1. Вірогідність виникнення респіраторних порушень у хворих на ЦД у разі виникнення в них гострого інсульту є високою (в нашому дослідженні - 63,3\%). Факторами ризику є чоловіча стать, ожиріння, високий бал за NIHSS (Г 15) при поступленні.

2. 3 метою точної і своєчасної діагностики СОАС у хворих на гострий інсульт та ЦД при поступленні потрібно проводити скринінг на порушення дихання з вимірюванням індексу апное-гіпопное, індексу десатурації та оцінку тяжкості СОАС для визначення необхідності і тактики респіраторної підтримки.

3. Тактика респіраторної підтримки повинна бути наступною:

о При виявленні хворих 3 «м'яким» COAC (IАГ 5-15) проводиться «позиційна» терапія, що включає регулярну зміну положення тіла 3 метою максимального зменшення часу перебування хворого в положенні на спині.

- У хворих з ІАГ Г 15 слід застосовувати методику ранньої неінвазивної вентиляційної корекції з використанням постійного позитивного тиску в дихаль- них шляхах (СРАР) у поєднанні з 40\% фракцією кисню у повітрі, що вдихається. - У разі виявлення у хворого СОАС тяжкого ступеню (ІАГ>20) та відсутності ефекту від СРАР-терапії протягом 2-3 діб, хворим показано переведення на ШВЛ 3 ранньою трахеостомією (метод вибору черезшкірна дилятаційна трахеостомія).

4. Особливостями розвитку СОАС у пацієнтів 3 гострим ішемічним інсультом та супутнім цукровим діабетом є швидке покращення показників у 1-3 дні лікування (за умови респіраторної підтримки) та потреба в тривалій терапії на подальших етапах. У цих хворих позиційна терапія і неінвазивна респіраторна підтримка можуть бути розпочаті рано при гарній переносимості і відносно невеликому ризику ускладнень.

\section{СПИСОК ЛІТЕРАТУРИ}

1. Геморагічний інсульт (внутрішньомозкова гематома, аневризмальний субарахноїдальний крововилив): екстрена, первинна, вторинна (спечіалізована) медична допомога та медична реабілітація. Уніфікований клінічний протокол медичноӥ допомоги. К.: Видавеиь Д.В. Гуляєв, 2012. - 96 с.

2. Зильбер А.П. Этюды респираторной медииины. М.: МЕД-пресс-информ, 2007.-792 с.

3. Шлапак I.П., Галушко О.А. Цукровий діабет: погляд з позииії лікаря-анестезіолога. - К.: Книга-плюс, 2010. - $160 \mathrm{c}$.

4. Javaheri $S$, Javaheri $S$, Javaheri A. Sleep apnea, heart failure, and pulmonary hypertension // Curr Heart Fail Rep. - 2013. - Dec; №10(4). - P.315-20. doi: 10.1007/ s11897-013-0167-3

5. Lin JJ, Lin KL, Wang HS et al. Occult infarct with acute hemorrhagic stroke in juvenile diabetic ketoacidosis // Brain Dev. - 2008. - №30(1). - P.91-93.

6. Nelles G, Busse O. Basistherapie auf der Stroke Unit. I In: Diener HC, Busch E, Grond M, Busse O. Stroke Unit Manual. - Stuttgart-New York; Thieme; 2005. - 208 p.

7. Priou P, Le Vaillant M, Meslier N. et al. Association between obstructive sleep apnea severity and glucose control in patients with untreated versus treated diabetes // J Sleep Res. - 2015. - Aug; №24(4). - P.425-31. doi: 10.11111 jsr.12278. Epub 2015 Feb 19.

8. Schober AK, Neurath MF, Harsch IA. Prevalence of sleep apnoea in diabetic patients // Clin Respir J. - 2011. Jul; №5(3). - P.165-72. doi: $10.1111 / j .1752$ 699X.2010.00216.x. Eрub 2010 Jun 30.

9. Shibazaki K, Kimura K, Uemura J. et al. Atrial fibrillation is associated with severe sleep-disordered breathing in patients with ischaemic stroke and transient ischaemic attack // Eur J Neurol. - 2013. - Feb; №20(2). P.266-70. doi: 10.1111/j.1468-1331.2012.03837.x.

10. Siccoli MM, Valko PO, Hermann DM, Bassetti CL. Central periodic breathing during sleep in 74 patients with acute ischemic stroke - neurogenic and cardiogenic factors // J Neurol. - 2008. - Nov; №255(11). - P.1687-92. doi: 10.1007/s00415-008-0981-9.

11. Sleep-related breathing disorders in adults: recommendations for syndrome definition and measurement techniques in clinical research. The Report of an American Academy of Sleep Medicine Task Force // Sleep. - 1999. - Aug 1; №22(5). - P.667-89. 
ORIGINAL RESEARCH

12. The European Stroke Organisation (ESO) Executive Committee; ESO Writing Committee. Guidelines for management of ischaemic stroke and transient ischaemic attack 2008 // Cerebrovasc Dis. - 2008. - №25(5). P.457-507. doi: 10.1159/000131083. Epub 2008 May 6.

13. Young T, Peppard PE, Gottlieb DJ. Epidemiology of obstructive sleep apnea: A population health

\section{PAIN, ANAESTHEESIA \& INTENSIVE CARE NA 2017}

perspective // Am J Respir Crit Care Med. - 2002. № 165. - P.1217-39.

14. Zhang R, Guo X, Guo L et al. Prevalence and associated factors of obstructive sleep apnea in hospitalized patients with type 2 diabetes in Beijing, China 2. // J Diabetes. 2015. - Jan; №7(1). - P.16-23. doi: 10.1111/17530407.12180 . Epub 2014 Sep 6.

\section{Галушко О.A.}

\section{СИНДРОМ ОБСТРУКТИВНОГО АПНОЭ СНА У БОЛЬНЫХ ОСТРЫМ ИНСУЛЬТОМ: ДИАГНОСТИКА И ТАКТИКА РЕСПИРАТОРНОЙ ПОДДЕРЖКИ}

Национальная медицинская академия последипломного образования имени П.Л.Шупика, 2. Киев

В результате проведенного исследования установлено, что вероятность возникновения синдрома обструктивного апноэ сна (СОAC) у больных острым инсультом (ОИ) является высокой (63,3\%). Факторами риска являются мужской пол, сахарный диабет (СД), ожирение, высокий балл по NIHSS (Г15). С целью диагностики СОАС и определения дальнейшей тактики респираторной поддержки у этих больных при поступлении нужно проводить скрининг-диагностику. Особенностями развития СОAС у пациентов с ОИ и сопутствующим СД является быстрое улучшение показателей в 1-3 дни лечения и потребность в длительной терапии на последующих этапах. Тактика респираторной поддержки у этих больных должна быть следующей. При выявлении больных с «мягким» СОАС (ИАГ 5-15) проводится «позиционная» терапия с целью максимального уменьшения времени пребывания больного в положении на спине. У больных с ИАГГ15 следует применять методику ранней неинвазивной вентиляционной коррекции с использованием постоянного положительного давления в дыхательных путях (СРAP). В случае выявления у больного СОАС тяжелой степени (ИАГ> 20) и отсутствии эффекта от СРАР-терапии в течение 2-3 суток, больным показан перевод на ИВЛ с ранней трахеостомией (метод выбора - чрескожная дилятационная трахеостомия).

ключевые слова: инсульт, сахарный диабет, синдром обструктивного апноэ сна, неинвазивная респираторная поддержка, СРАР-терапия, дилятационная трахеостомия.

\section{Halushko 0.}

\section{SLEEP APNEA SYNDROME IN PATIENTS WITH ACUTE STROKE: DIAGNOSTICS AND TACTICS OF RESPIRATORY SUPPORT FEATURES}

National Medical Academy of Postgraduate Education named PLShupyk, Kiev

The study found that the risk of respiratory disorders in diabetic patients with acute stroke (AS) is high (63.3\%). Risk factors include male gender, obesity, high NIHSS score (Г15). For the purpose of diagnosing disorders of breathing during sleep in these patients should be performed at admission screening diagnosis of obstructive sleep apnea (OSA) to determine the need for respiratory support and tactics. The tactics of respiratory support in these patients should be as follows. When detecting patients with "soft" OSA (IAH 5-15), "position" therapy is performed to minimize the patient's stay in the position on the back. In patients with $\mid A H>15$, a technique of early non-invasive ventilation correction using constant positive airway pressure (CPAP) should be used. In the case of severe OSA (IAH> 20) and absence of CPAP-therapy effect for 2-3 days, the patient the patient is ventilated with early tracheostomy (the method of choice is percutaneous dilatational tracheostomy).

Key words: stroke, diabetes mellitus, obstructive sleep apnea syndrome, non-invasive respiratory support, CPAP therapy, dilated tracheostomy. 